\title{
UTLÅN OG AVHENDING AV MATERIALE FRA NORSKE MUSEUMSSAMLINGER
}

\author{
Jon Birger Østby
}

Norge har en kort historie som selvstendig nasjon. Landet har ikke hatt kolonier, og museene har relativt små samlinger av utenlandsk materiale. Museene har noe materiale som er brakt hjem av norske oppdagelsesreisende. Noen samlinger er kommet til landet med hjemvendte misjonarer, og noe utenlandsk materiale har kommet til museene gjennom norske borgere som har drevet forretningsvirksombet eller hatt annet arbeid $i$ utlandet. Det har vert svart fä foresporsler om tilbakeforing av materiale til andre stater, men det fremmes stadig ønsker fra regioner eller lokalsamfunn om tilbakeforing av materiale fra de sentrale museenes samlinger og stadig flere av disse sakene blir fulgt opp i politiske fora.

Oppnevningen av det utvalget som det her gjøres rede for, er et direkte resultat av de ønsker som er reist av Arkeologisk museum i Stavanger, om å få overført arkeologisk materiale fra Rogaland som i dag befinner seg i samlingene ved Bergen museum og Universitetets kulturhistoriske museer i Oslo. Denne saken reiste et betydelig politisk engasjement, og den viste et klart behov for at man innenfor museumssektoren selv burde drøfte generelle prinsipper og holdninger til slike spørsmål. Nasjonalt utvalg for universitetsmuseene og Norsk museumsutvikling har derfor samarbeidet om å oppnevne utvalget.

I et samfunn som er i rask utvikling, må museene tilpasse seg nye eller endrede forutsetninger, og i mange tilfelle vil slike endringer også bidra til å reise spørsmål rundt framtidig forvaltning av museenes samlinger. Utvalget har ikke tatt sikte på å gi konkrete løsninger på de dagsaktuelle sakene på dette området, men vi har hatt som siktepunkt å gi en veiledning til museer og politiske myndigheter om hvilke hensyn og avveininger museene må foreta når spørsmål om utlån eller avhending blir reist. 


\section{UTVALGETS SAMMENSETNING OG RAPPORT}

Utvalget har hatt følgende sammensetning:

Jon Birger Østby, Norsk museumsutvikling (leder)

Henrik von Achen, Nasjonalt utvalg for universitetsmuseene (Bergen Museum, Universitetet i Bergen)

Liv Hilde Boe, Norsk Folkemuseum

Ove Magnus Bore, Norges museumsforbund (Stavanger Museum)

Olav Hogstad, Nasjonalt utvalg for universitetsmuseene (Vitenskapsmuseet, (NTNU)

Berit Åse Johnsen, Samiid Vuorka-Davvirat (De samiske samlinger)

Egil Mikkelsen, Nasjonalt utvalg for universitetsmuseene (Universitetets kulturhistoriske museer, Universitetet i Oslo)

Arne C. Nilssen, Nasjonalt utvalg for universitetsmuseene (Tromsø Museum, Universitetet i Tromsø)

Jenny-Rita Næss, Arkeologisk museum i Stavanger

Ovin G. Udø, Norges museumsforbund (Agder naturmuseum og botaniske hage)

I rapporten behandler utvalget følgende områder:

- Museenes formål med samlinger

- Museenes forvaltningsansvar for og eiendomsrett til samlinger

- Generelle kriterier som bør vurderes ved spørsmål om utlån eller avhending

- Utlån og deponering av materiale til andre museer

- Utlån, deponering og avhending av materiale fra museer til andre arenaer

- Avhending ved bytte, destruksjon eller salg

- Tilbakeføring av museumsmateriale til den samiske urbefolkning

- Overføring av museumsmateriale til nasjonale minoriteter
- Tilbakeføring av ulovlig importert materiale som er i museers besittelse

- Ressursbruk og omfang av utlån

- Anbefalinger om saksbehandling og avtaler

I denne sammenheng skal jeg orientere om de generelle kriterier som utvalget anbefaler at museene bør legge til grunn for vurdering av utlån eller avhending av materiale, om de særlige anbefalinger som utvalget kommer med $\mathrm{i}$ håndtering av det samiske materialet og om håndtering av materiale som har tilknytning til nasjonale minoriteter. For dem som også er interessert i de andre delene av utvalgets rapport viser jeg til den fullstendige versjonen. ${ }^{1}$

\section{GenERELle Kriterier} SOM BØR VURDERES VED SPØRSMÅL OM UTLÅN ELLER AVHENDING

Museer bør behandle alle forespørsler om utlån eller overføring av materiale fra samlingene seriøst og respektfullt. Ved slike henvendelser må museene foreta en avklaring av de juridiske, etiske og museumsfaglige spørsmål som kan ha betydning for saken. Museene bør legge spesiell vekt på å sette seg inn i de interesser og behov som ligger til grunn for at spørsmål om utlån/overføring er reist. Det er viktig at museet sørger for at saksbehandling, begrunnelse og betingelser som knyttes til eventuelle avtaler, er forsvarlig dokumentert for ettertiden. Museene må rette seg etter nasjonal og internasjonal lovgivning og sørge for at forvaltningen av samlingene skjer i samsvar med gjeldende juridiske forpliktelser og institusjonens vedtekter. 


\section{TILRÅDINGER}

I arbeidet for å finne fram til generelle retningslinjer for overføring og utlån har utvalget blitt stående ved følgende åtte hensyn som må veies mot hverandre:

1. Museene skal tjene samfunnet og samfunnets interesser, og samlingene forvaltes på vegne av samfunnet. Dette er et overordnet prinsipp som bør ligge til grunn for museenes håndtering $\mathrm{av}$ forespørsler om lån og utlevering av samlinger.

2. Ved forespørsel om utlån eller avhending skal det aktuelle materialets forskningsmessige sammenheng tillegges stor vekt. Av hensyn til forskning og for å kunne gi en formidling med linjer i tid og rom, er det ønskelig å ha noen samlinger som synliggjør regionale, nasjonale og/eller internasjonale sammenhenger. Dette hensyn må veie tyngre enn en lokalbefolknings ønske om å oppbevare materialet på dets funn- eller opprinnelsessted.

3. Som hovedregel bør museene være sarlig velvillige ved forespørsler om lån til midlertidige utstillinger av materiale som ikke er utstilt eller $\mathrm{i}$ annen aktiv bruk.

4. Museene har et særlig ansvar for å stille samlinger til disposisjon for institusjoner for urbefolkninger og etniske/nasjonale minoriteter.

5. En forutsetning for utlån eller overføring må være at transporten skjer under betryggende forhold, og at den lånende institusjonen har tilgang til faglig kompetanse og fysiske forhold som sikrer en forsvarlig håndtering under låneperioden.

6. Ved utlån eller overføringer må det stilles krav til kompetanse på håndtering av materialet og til fysiske oppbevaringsforhold ved den mottakende institusjonen.
7. Ved spørsmål om permanent overføring av større, magasinerte samlinger bør det gjøres en vurdering av kostnadene $\mathrm{i}$ forhold til den samfunnsmessige gevinsten ved overføringen.

8. Alle museer har et generelt ansvar for å gjøre innholdet i samlingene kjent gjennom kataloger som er tilrettelagt for bruk av et allment publikum. I forskning, undervisning og i utstillinger vil det alltid være behov for tilgang til det originale materialet. Men med moderne informasjonsteknologi vil felles bruk og tilgang til museers samlinger være vesentlig enklere enn før. I flere tilfeller kan det derfor være viktigere at museene satser på å åpne tilgang til "magasinert" materiale gjennom elektroniske kunnskapsbanker, framfor å flytte store samlinger mellom ulike magasin.

\section{TILBAKEFøRING}

AV MUSEUMSMATERIALE

TIL DEN SAMISKE URBEFOLKNING

Grunnlovens $\$ 110$ a og Sameloven av 12. juni 1987 med senere endringer er rammebetingelser for arbeid med samiske spørsmål i Norge. Med disse to internrettslige medbestemmelsene er samene definert som et eget folk og en egen juridisk kategori i den norske lovgivningen og forvaltningen. Grunnlovens $\$ 110$ a uttrykker att: Det paaligger statens myndigheter at lagge forholdene til rette for at den samiske folkegruppe kan sikre og utvikle sitt sprog, sin kultur og sitt samfunnsliv. I dette ligger det at den norske stat har plikt til å medvirke aktivt til at samisk kultur blir videreført i Norge. Dette innebærer også en plikt til, gjennom økonomisk og annen virkemiddelbruk, å legge forholdene til rette for en rimelig grad av reell resultatlikhet for mi- 
noritetens og majoritetens kulturutøvelse.

$\AA$ legge forholdene til rette for at samene kan videreføre og utvikle sin kultur forutsetter at det utvikles en kulturpolitikk der målet er reell likeverdighet mellom samisk kultur og norsk kultur. Regjeringen har i Stortingsmelding 41 (1996-97) Om norsk samepolitikk uttrykt det som et klart mål å føre en mest mulig helhetlig samepolitikk. Her heter det blant annet: Norsk samepolitikk hviler på en rettstilstand som pålegger myndighetene à legge forholdene til rette for at den samiske folkegruppe skal kunne sikre og utvikle sitt språk, sin kultur og sitt samfunnsliv. Denne politikken må $i$ størst mulig grad vare basert på samenes egne premisser. Her vil Sametinget, som folkevalgt organ, vere den viktigste premissleverandøren.

I Sametingsplan 1998-2001 framheves det at for å møte de samfunnsmessige utfordringene, er det avgjørende at de samepolitiske virkemidlene fornyes $\mathrm{i}$ takt med endringer av rammevilkår. Kulturell forankring og fleksibilitet, kontinuitet og endringer er sentrale begreper i denne sammenheng. Planen uttrykker videre at samene har kollektiv rett til å bestemme over egen framtid. Retten til selvbestemmelse medfører også retten til å delegere beslutningsrett fra Sametingets side.

Ved siden av norske rettsregler og målsettinger er grunnlaget for norsk samepolitikk definert av prinsipielle retningslinjer nedfelt i folkeretten. ${ }^{2}$

Av direkte relevans for utforming av en samisk museumspolitikk er Utkast til De forente Nasjoners deklarasjon om urfolks rettigheter, som er utformet av Arbeidsgruppen for urfolk under FNs Menneskerettighetskommisjon. Det er en erklært målsetting at deklarasjonen skal ferdigstilles innen urfolks-tiåret. Artikkel 12 uttrykker at urfolk har rett til å vedlikeholde, verne og utvikle fortidige, nåtidige og framtidige kulturelle manifestasjoner, så som arkeologiske og historiske kulturminner, gjenstander, mønstre, seremonier, teknologier og visuell og utøvende kunst, likeså retten til å få tilbakelevert kulturell, intellektuell, religiøs og åndelig eiendom som er ervervet uten deres frie og informerte samtykke, eller gjennom overtredelse av deres lover, tradisjoner og skikker.

Et annet dokument utarbeidet av arbeidsgruppen for urfolk er Utkast til prinsipper og retningslinjer for vern av urfolks kulturarv, bifalt av underkommisjonene for bekjempelse av diskriminering i 1997. Også dette arbeidet ønskes ferdigstilt innen urfolks-tiåret. Blant prinsippene er at vern av urfolks kulturarv bør baseres på prinsippet om selvbestemmelse, og at urfolk bør anerkjennes som de primære beskyttere og fortolkere av sin egen kultur, enten den er skapt i fortiden eller utvikles i framtiden. Retningslinjene anbefaler at myndigheter bør støtte urfolk i deres bestrebelser på å få tilbake kontroll over og besittelse av kulturarven. De innebærer videre at museale samlinger ved museer og universitet bør tilbakeføres dersom det kreves, eventuelt at det inngås avtaler om former for samarbeid om forvaltning der de befinner seg. Også innsamling og utstilling bør skje gjennom avtaler som også lar seg reforhandle.

Museumsspørsmål dreier seg om et meget sentralt samisk kulturvern- og kulturutviklingsområde. Forvaltningen av de samiske museene er nå overført fra Kultur- og kirkedepartementet til Sametinget, og en overføring av myndighet på dette feltet vil innebære en reell innflytelse over egen kulturutvikling.

Ved forhandlinger om tilbakeføring av samisk materiale kan det være av stor nytte å 
46 trekke på de erfaringer som man har i andre land. Canadian Museum of Civilization i Ottawa, Canada, er et av de museene som har utviklet en klar politikk på dette området. Museet tar ikke selv initiativ til tilbakelevering av materiale til urfolk. Men når folkegrupper selv fremmer krav, så behandles de i hovedsak etter følgende prinsipper:

1. Alle gjenstander med rituell betydning returneres hvis gruppen ønsker det.

2. Den øvrige samlingen deles i tre. En del returneres på permanent basis til folkegruppen. En del beholdes på permanent basis i museet, blant annet til bruk i permanente utstillinger. En tredjedel forvaltes i samarbeid mellom museet og folkegruppen, blant annet for å kunne møte ønsker om utlån til skiftende utstillinger.

3. Parallelt med utleveringen gir museet bistand til gruppen om håndtering av museumsmateriale, rådgiving om oppbygging og drift av museer, og i en del tilfelle arrangeres det egne hospitant/opplæringsprogram i museet for å kvalifisere representanter i forvaltning av samlingene.

Generelt sett er kunnskapen om samisk historie og samiske forhold liten utenfor de samiske områdene. Den kunnskap og innsikt som kan skapes gjennom museenes formidling er derfor viktig. For alle museer som forvalter samisk materiale, er det derfor en felles utfordring å formidle samisk kultur til samer og andre innbyggere i regionene og til tilreisende fra inn- og utland. Museene skal være en møteplass der folk kan tilbys økt kunnskap om og stilles overfor spørsmål omkring samisk historie og nåtid og om samspill og konflikt mellom det samiske samfunnet og andre grupperinger. En slik formidling må sees både $\mathrm{i}$ lys av historiske og dagsaktuelle forhold. Det er behov for problemorienterte diskusjoner om forståelsesrammene for kunnskapsproduksjon, formidlingsideologi og målsettinger om hvordan museene samlet kan gi en bred og allsidig dekning av sine felt, tjenlig både for det samiske samfunnet og for storsamfunnet.

De samiske museene har generelt sett lite gjenstandsmateriale, og mulighetene for innsamling av eldre materiale er i dag svært begrenset. Gjenstandsmaterialet er basis for de samiske museers bidrag i utvikling av kunnskap om historiske, kulturelle og miljømessige sammenhenger. Materialet er også viktig for samisk kulturutøvelse, og gjenstandene danner grunnlag for kommunikasjon og refleksjon om tilhørighet til den samiske kulturen både på individ- og gruppenivå. Utvalget mener derfor at museer som har samiske samlinger har et spesielt ansvar for å stille disse til disposisjon for samiske museer. Utvalget ser også et klart behov for å vurdere de mange sakene som fremmes på dette området $\mathrm{i}$ sammenheng.

På samme måte som man i Canada ser at det er viktig at urfolks kultur også i framtiden skal kunne presenteres i Ottawa, mener utvalget at forskning på og formidling av samisk kultur også i framtiden er et ansvarsområde for det norske storsamfunnet og dermed også for de norske museene. Sentrale museer i Tromsø og Oslo vil være viktige i denne sammenheng. Utvalget vil anbefale at dette er et element som legges til grunn ved eventuelle forhandlinger om framtidig forvaltning av det samiske museumsmaterialet.

Sametinget er samenes politiske organ, og utvalget mener derfor at Sametinget bør ha en sentral rolle i å utforme en framtidig politikk for forvaltning av det samiske materialet som i dag befinner seg i museene, både når det gjelder framtidig oppbevaringssted, forsk- 
ning og formidling, og at Sametinget, eller et organ utpekt av Sametinget, derfor bør representere de samiske interessene ved forhandlinger om tilbakeføring av samisk museumsmateriale.

\section{TILRÅDINGER}

1. Museene har et særlig ansvar for å stille samlinger til disposisjon for institusjoner for urbefolkninger.

2. Det er viktig at samisk historie og kultur formidles både i og utenfor de samiske områdene. Museer som forvalter samiske samlinger har et særlig ansvar for å bidra til dette.

3. Utvalget slår fast at det er en prinsipiell forskjell mellom å vurdere tilbakeføring av materiale til den samiske urbefolkningen og å tilbakeføre materiale til norske regioner eller lokalsamfunn. For tilbakeføring av samisk materiale bør museene rette seg etter de målsettinger som er trukket opp både i nasjonal lovgivning om samepolitiske målsettinger og etter internasjonale konvensjoner og avtaler som omhandler urfolk.

4. Sametinget bør være forhandlingspart ved diskusjoner om overføring og framtidig forvaltning av det samiske materialet. Anmodninger om overføring av samlinger med samisk materiale utover utlån til utstillinger eller andre klart tidsavgrensete formål bør derfor gå via Sametinget.

5. Sametinget bør i samarbeid med museene som forvalter samisk materiale, utarbeide en oversikt over det samiske materialet i museenes samlinger i Norge.

6. Det er en sentral utfordring å prioritere elektronisk tilgjengeliggjøring av samisk materiale i sentrale samlinger, og man bør vurdere å opprette et sentralregister for

\section{Overføring aV MUSEUMSMATERIALE TIL NASJONALE MINORITETER}

Stortinget ga våren 1998 samtykke til at Norge skulle ratifisere Europaradets rammekonvensjon av 1. februar 1995 om beskyttelse av nasjonale minoriteter (St prp nr 80 (1997-98)), og det innebærer en forpliktelse også for museene.

I Norge er jøder, kvæner, rom (sigøynere), romanifolket (tatere/de reisende) og skogfinner definert som nasjonale minoriteter. Det er viktig at museene bidrar til å synliggjøre de nasjonale minoritetskulturene, ikke bare for at disse gruppene skal få bedre kjennskap til egen kultur, men også for at storsamfunnet skal få bedre kunnskap om dem. $\AA$ underslå at deres kultur og historie er en del av Norges kultur og historie, vil i praksis innebære en forfalskning av historien vår.

I kap. 4 i Europarådets konvensjon om nasjonale minoriteter heter det:

I konvensjonens fortale vises det til at omveltningene i europeisk historie har vist at beskyttelsen av nasjonale minoriteter er avgjørende for stabilitet, demokratisk sikkerhet og fred i Europa, og at man er fast bestemt på å beskytte nasjonale minoriteters eksistens. Det slås videre fast at et pluralistisk og genuint demokratisk samfunn ikke bare må respektere den etniske, kulturelle, språklige og religiøse identiteten til personer som tilhører nasjonale minoriteter, men også må legge forholdene til rette for at disse personene kan uttrykke, bevare og utvikle sin identitet. De kontraherende stater tar også i betraktning at det er nødvendig å skape en atmosfære av toleranse og dialog for at kulturelt mangfold skal kunne bli en kilde, ikke til splittelse, men til berikelse for hvert samfunn. 
48 Artikkel 5 pålegger statene å legge forholdene til rette for at personer som tilhører nasjonale minoriteter kan bevare og utvikle sin kultur og identitet, og ikke bli gjenstand for tvungen assimilering: (...) Staten skal bidra til a fremme kulturell likestilling mellom minoritetskulturer og storsamfunnet, og det vil vare opp til de statlige myndigheter a vurdere hvilke tiltak som er nødvendige for à realisere denne målsettingen.

Hvis vi ser på museumssatsinger som har nasjonale minoriteter som hovedtema, er det et lite jødisk museum i Trondheim. Vadsø museum har et særlig ansvar for kvænkultur og i Porsanger bygges det et kvænsenter som særlig skal arbeide med kvænsk språk. I Hedmark drøfter man hvordan man videre skal følge opp museumsansvaret for skogfinnene og Glomdalsmuseet og Levanger Museum arbeider med å utvikle museumstilbud for og om romanifolket. Etter det utvalget kjenner til er det ingen museer som så langt har arbeidet spesielt med sigøynerkultur.

\section{TILRÅDINGER}

Norske museer har relativt lite materiale som dokumenterer nasjonale minoriteter. Men i den grad slikt materiale finnes, bør museene vise særlig imøtekommenhet i forhold til forespørsler om utlån og eventuell overføring til museer som drives av, eller i samarbeid med, nasjonale minoriteter.

\section{Avslutning}

Som overordnet prinsipp anbefaler utvalget at museene i spørsmål om eiendomsrett og forvaltning av samlingene tar utgangspunkt i ICOMs formålsparagraf. Her heter det at museene skal tjene samfunnet og samfunnets utvikling. Med et slikt utgangspunkt vil museenes grunnholdning måtte være at de forvalter samlingene på samfunnets vegne. Det innebærer at museene ikke bare kan vurdere spørsmål om utlån og avhending ut fra institusjonenes egne primære behov og ønsker. De juridiske hindringer som eventuelt skaper problemer for å kunne følge opp en samfunnsrettet politikk for utlån og avhending, bør da snarere betraktes som utfordringer enn som permanente hindringer.

\section{Noter}

1. Utlån og avhending av materiale fra museenes samlinger. Norsk museumsutvikling. Rapport nr. 5, 2000 .

2. FNs konvensjon av 1966 om sivile og politiske rettigheter, art 27, ILO konvensjonen av 1969

Om urbefolkninger og stammefolk i selvstendige stater, FNs konvensjon om barns rettigheter, FNs konvensjon om biologisk mangfold art. 8(j) og Agenda 21 fra verdenskonferansen for miljø og utvikling kap. 26.

\author{
Direktor Jon Birger Østby \\ Adr. ABM-utvikling, Postboks 8045 Dep., \\ N-0030 Oslo \\ Fax: +4723239441 \\ E-mail: jon.birger.ostby@museumsnett.no
}

